Original Article

\title{
Use of Dried Basil Leaves as a Feeding Attractant for Hybrid Tilapia, Oreochromis niloticus X Oreochromis aureus, Fingerlings
}

\author{
A. Y. El-Dakar ${ }^{1}$, G.D. Hassanien ${ }^{1}$, S.S. Gad ${ }^{2}$ and S.E. Sakr ${ }^{1}$
}

${ }^{1}$ Fish Resources and Aquaculture Department, Faculty of Environmental Agricultural Sciences Suez Canal University, El-Arish, North ${ }^{1}$. Sinai, Egypt. ${ }^{2}$ Food Technology Department, Faculty of Environmental Agricultural Sciences, Suez Canal University, El-Arish, North Sinai, Egypt. ${ }^{2}$.

\begin{abstract}
A use natural feed additive is becoming useful for fish feeding rather than classic chemical feed additives due to the accumulative effect of the chemical components induced deterrent effects on human health. We study the effects of different levels of dried basil leaves (DBL) on performance, body composition and cost-benefit analysis of hybrid tilapia, Oreochromis niloticus $x$ O. aureus. Four experimental isonitrogenous and isoenergitic diets were formulated to contain $0,0.5,1.0$ and $2.0 \%$ of DBL. Eight glass aquaria (96-L) were used in duplicates to stock ten fish having the same initial weight $(13 \mathrm{~g} /$ fish) in each. Fish were fed $3 \%$ of the body weight three times daily, six days a week for 112 days. The dried basil leaves improved digestibility of protein and energy and declined the digestion of lipid and carbohydrates. Incorporation of DBL in test diets improved significantly $(\mathrm{P}<0.05)$ growth rate than the control diet especially at $2 \%$ DBL which achieved the best inclusion level. Palatability index increased as DBL levels increased and resulted in a reduction in feed waste percent from $33.48 \%$ with the control diet to $8.43 \%$ with diet contained $2 \%$ DBL level. Consequently, low incidence cost and high profit index were significantly $(\mathrm{P}<0.05)$ with the diet containing $2 \% \mathrm{DBL}$ level. There is a positive impact for growth and feed efficiency to use DBL in Tilapia feeds.
\end{abstract}

Key Words: Feeding attractants, Basil level, Hybrid tilapia, Feed waste, Palatability index.

Received : 3 August 2007

Accepted : 20 December 2007

Correspondence:

Ashraf Y. El-Dakar

Fish Resources and Aquaculture Department, Faculty of Environmental Agricultural Sciences, Suez Canal University,

El-Arish. Egypt. Tel. :+20126129896; Fax: +2068633203

E-mail: a_eldakar@yahoo.com

Copyright : All rights reserved to Mediterranean Aquaculture and Environment Society (MAEPS) 


\section{Introduction}

Using medicinal herbs in human feeding is a well-known culture thousands of years in ancient Egypt, India and China. These herbs/plants have been used as spices and medicinal additives in different animals e.g. pekin duck (Karali, 1995), broilers (Hanafy, 1995), abalone (Harada and Kawasaki, 1982 and Harada, 1987), fish (Atwa, 1997; Abou-Zied, 1998; Abd Elmonem, et al. 2002; Shalaby, et al. 2003; El-Dakar, et al. 2004; El-Dakar, 2004; Shalaby, 2004 and El-Dakar, et al. 2007) and shrimp (El-Dakar, et al. 2005). Spices such as garlic and onion were added to some baits for commercial and sport fishing in Japan (Harada, 1992). In addition, natural herbs and spices are incorporated in feeds only in small amounts, but they make important contributions towards the odour and flavor due to presence of volatile and fixed oils. Use of marjoram leaves as a feeding attractant in fish feeding resulted in an improvement in growth, feed conversion, protein utilization and protein and energy digestibilities of hybrid tilapia (El-Dakar, et al. 2004). Also, increasing of their levels up to $2-3 \%$ has led to paramount economic success (Mendoza, et al. 1997; Shalaby, et al. 2003; El-Dakar, et al. 2004; Shalaby, 2004 and El-Dakar, et al. 2005). Use of natural herbs-medicinal and aromatic plants in fish feeding is still limited on the experimental and commercial scales. However, few studies have been conducted to utilize these herbs and plants as feed additives to enhance growth and feed efficiency. The present study aimed to investigate the effect of different levels of dried basil leaves (DBL) on growth performance, feed and protein conversion, nutrient retention efficiencies, feeding attraction, nutrient digestibility and cost-benefit analysis of hybrid tilapia, $O$. niloticus $x O$. aureus, fingerlings.

\section{Materials and Methods}

This work was carried out at Wet Lab. of the Fish Resources and Aquaculture Department, Faculty of Environmental Agricultural Sciences, Suez Canal University, El-Arish, North Sinai, Egypt. Wet Lab was designed as a closed system (recirculating system). Eight aquaria $(60 \times 40 \times 50 \mathrm{~cm} ; \mathrm{LxWxH}, 96-\mathrm{L}$, net water volume), two aquaria per treatment, were arranged in series and received recirculating filtered water at $0.5 \mathrm{~min}$. Water leaving aquaria was allowed to enter in a sedimentation basin where solids were removed. The water was then passed into a biological filter using water pump, where bacteria detoxify ammonia and nitrite into nitrate. The biological filter was followed by a reservoir tank $\left(1-\mathrm{m}^{3}\right)$ in order to regulate water level of each aquarium using overflow tubes. Two blowers were used for aeration through air stones.

Fingerlings of hybrid tilapia $O$. niloticus $x$ $O$. aureus were obtained from a private fish farm at El-Fayoum Governorate, Egypt. After arrival, all fish were kept for one week in fiberglass tanks (600-L capacity) to alleviate stresses during transportation and to be adapted to the new conditions. Ten fish of the same initial weight (13g/fish) were selected and randomly distributed into experimental aquaria. Fish were fed the control diet for two weeks, during this period healthy fish of the same weight replaced the dead ones. Fish were reared in $28.5 \pm 2.5^{\circ} \mathrm{C}, 5.65 \pm 0.5 \mathrm{mg} / \mathrm{L}, 8.5 \pm 0.3$ and $12 / 12 \mathrm{~h}$ Light/Dark for temperature, dissolved oxygen, salinity, $\mathrm{pH}$ and photoperiod, respectively. Temperature and salinity were measured daily using S-C-T meter model YSI33 and $\mathrm{pH}$ was measured by $\mathrm{pH}$ meter model Jenway, 3060.

Four experimental diets were formulated to contain $0,0.5,1.0$ and $2 \%$ DBL which was obtained from Medicinal and Aromatic Plants Company, El-Fayoum Governorate, Egypt. All the experimental diets contained similar percentages of fish meal, meat meal, soybean meal and oil. Ingredients composition of the diets is presented in (Table 1).

The experimental diets were prepared by mixing dry ingredients with water and were pelleted using a meat mincer with a $1.5-\mathrm{mm}$ diameter. 
Table 1: Ingredients composition (\%) of the experimental diets.

\begin{tabular}{|c|c|c|c|c|}
\hline \multirow{2}{*}{ Ingredients } & \multicolumn{4}{|c|}{ Diet No } \\
\hline & 1 & 2 & 3 & 4 \\
\hline Fish meal $^{1}(72 \% \mathrm{CP})$ & 20.0 & 20.0 & 20.0 & 20.0 \\
\hline Meat meal ${ }^{2}(54 \% \mathrm{CP})$ & 10.0 & 10.0 & 10.0 & 10.0 \\
\hline Soybean meal ${ }^{3}(48 \% \mathrm{CP})$ & 26.0 & 26.0 & 26.0 & 26.0 \\
\hline Wheat flour ${ }^{4}$ & 34.0 & 33.5 & 33.0 & 32.0 \\
\hline Dried basil leaves (DBL) & 0.0 & 0.5 & 1.0 & 2.0 \\
\hline Linseed oil ${ }^{5}$ & 6.0 & 6.0 & 6.0 & 6.0 \\
\hline Vitamin and Minerals premix ${ }^{6}$ & 4.0 & 4.0 & 4.0 & 4.0 \\
\hline Total & 100 & 100 & 100 & 100 \\
\hline
\end{tabular}

1. Herring fish meal, Revisen, Co, Denmark.

2. Sabi Co. Italy.

3. Kafer El-Zayyate Extracted OilsCo. Kafer El-Zayyte, Egypt.

4. East Delta milling Co. El-Arish, North Sinai, Egypt.

5. El-Mahala El-Kobra Extracted Oil Co. Egypt.

6. Vitamins and minerals premix (New Gellemix product) each $1 \mathrm{~kg}$ contained: $10.000 .000 \mathrm{IU}, 1.100 .000 \mathrm{IU}, 1.000 \mathrm{mg}, 400 \mathrm{mg}$, $600 \mathrm{mg}, 1.200 \mathrm{mg}, 4.50 \mathrm{mg}, 6500 \mathrm{mg}, 80 \mathrm{mg}, 3250 \mathrm{mg}, 1500 \mathrm{mg}, 1200 \mathrm{mg}, 50 \mathrm{mg}, 50 \mathrm{mg}, 175.000 \mathrm{mg}, 120 \mathrm{mg}, 15.000 \mathrm{mg}, 35.000 \mathrm{mg}$, $1.250 \mathrm{mg}, 31.250 \mathrm{mg}, 500 \mathrm{mg}$, 50mg and $125 \mathrm{mg}$ of vitamin A, D3, E, B $, \mathrm{B}_{2}, \mathrm{~B}_{6}, \mathrm{~B}_{12}, \mathrm{PP}$, Biotien, d-pantothenic acid, $\mathrm{K}_{3}$, C, Inositol, folic acid, choline $\mathrm{HCl}$, cobalt, iron, manganese, copper, zinc, iodine, selenium, and BHT, respectively. Meal vegetable and calcium carbonate up to $1000 \mathrm{~g}$.

The pellets were air dried and stored at $-20^{\circ} \mathrm{C}$ until use. Fish were fed the experimental diets at a rate of $3 \%$ of the body weight daily, at three times a day (900, 1200 and 1500), six days a week for 112 days. Fish were weighed biweekly and feed amounts were adjusted on the basis of the new weight. During the last two weeks, uneaten feed was removed from aquaria by siphoning after being weighed daily to calculate voluntary feed intake, feed waste $\%$ and palatability index. Every morning of the last two weeks faeces were collected by siphoning, separated from water, weighed and stored at $-20^{\circ} \mathrm{C}$ for analysis. Apparent digestibility coefficient (ADC) was determined using the direct method according to Lovell (1989). Ingredients, diets, faeces and fish samples were analyzed according to AOAC (1990) for dry matter, crude protein, ether extract, crude fiber, nitrogen free extract (NFE) and ash.

The essential oil was prepared by hydro distillation of dried leaf powder according to Balbaa et al. (1981). The essential oil and effective compounds of DBL were determined by using GC-MS, gas chromatography that equipped with DB-5 fused silica capillary column HP, $50 \mathrm{~m}$ length, $0.3 \mu \mathrm{m}$ thickness and $\mathrm{Ni}$ electron capture detector. Auto sampler (Hewelett Packard model 68900) was used to inject $2 \mu \mathrm{l}$ of essential oil with splitless injections technique. The operation conditions were as follows, injector temperature was $200^{\circ} \mathrm{C}$; carrier gas was Helium at $0.8 \mathrm{~cm} / \mathrm{min}$, oven temperature was $40^{\circ} \mathrm{C}$ and detector temperature was $300^{\circ} \mathrm{C}$. GC-MS was operated in a selected ion monitoring mode. Chromatography analysis was carried out according to Adams (1989). Cost-benefit analysis (incidence cost, IC and profit index, PI) for DBL inclusion in diets of tilapia fingerlings were calculated according to New (1985).

Analysis of variance (ANOVA) was carried out according to Sandecor and Cochran (1974) using a completely randomized design (CRD). Differences were subjected to Duncan's Multiple Range-Test (Duncan, 1955) at 0.05 significance level. All statistical tests were preformed using the MStat-C (1988) software. 


\section{Results}

Dried basil leaves composition was shown to contain $12.99 \%$ crude protein and $367 \mathrm{kcal} / 100 \mathrm{~g}$ gross energy. It was rich in carbohydrate (49.74\%), however, ether extract, crude fiber and ash percentages were found as 9.57, 14.81 and $12.89 \%$, respectively (Table 2 ).

All the experimental diets were isonitrogenus and isocaloric. The crude protein and gross energy values were around $33 \%$ and 446 $\mathrm{kcal} / 100 \mathrm{~g}$ diet, respectively. At the same time, adding the DBL resulted in an improvement for both digestible protein and digestible energy (Table 2). Essential oil content of DBL was $1.51 \%$ (Table 3 ).

The effective substrates present in DBL were ocimene, methyl chavecol and linalool which represent $21.64,14.99$ and $10.20 \%$ of essential oil, respectively. Inclusion of DBL in fish diets showed higher significant $(\mathrm{P}<0.05)$ protein and energy digestibility coefficients (Table 4). Meanwhile, it showed lower significant ( $\mathrm{P}<0.05$ ) in digestibilities lipid and carbohydrates. While differences in dry matter and crude fiber digestibility coefficients were not significant $(\mathrm{P}>0.05)$ among the fish fed diets containing different DBL levels as feed attractants. Data in (Table 5) showed that incorporation of DBL at levels of 0.5, 1.0 and $2.0 \%$ in hybrid tilapia diets general improved significantly final weight, weight gain and SGR as compared with the control diet $(0 \%$ DBL). Fish fed diet contained $\%$ DBL showed significantly $(\mathrm{P}<0.05)$ superior in growth performance parameters versus to the other fish groups. The highest SGR was recorded by fish fed $2 \%$ DBL followed by $1 \%$ and $0.5 \%$. However the control diet gave the lowest growth. Survival rate was in the normal range, it ranged between 100 and $95 \%$ for all fish groups. Condition factor was insignificant $(\mathrm{P}>0.05)$ among all fish groups. However, statistical analysis showed no significant differences $(\mathrm{P}>0.05)$ was found in the feed intake among all fish groups. It increased with increasing of DBL in the experimental diets. Feed conversion ratio was better with $2 \%$ followed by $1 \%$ DBL level. Fish fed the control diet and $0.5 \%$ DBL level showed lower FCR than those fed other levels. Protein efficiency ratio was improved with increasing level of DBL in hybrid tilapia diets. However, differences in productive protein value and energy retention values were not significant $(\mathrm{P}>0.05)$ among all fish fed the experimental diets (Table 5).

Table 2: Chemical proximate analysis of the experimental diets.

\begin{tabular}{|c|c|c|c|c|c|}
\hline \multirow[t]{2}{*}{ Item } & \multirow[t]{2}{*}{$\mathrm{DBL}^{1}$} & \multicolumn{4}{|c|}{ Diet No. } \\
\hline & & 1 & 2 & 3 & 4 \\
\hline Dry matter & 92.28 & 92.82 & 91.64 & 91.59 & 91.41 \\
\hline \multicolumn{6}{|l|}{$\%$ of DM basis } \\
\hline Crude protein & 12.99 & 33.55 & 33.58 & 33.61 & 33.63 \\
\hline Crude Lipids & 9.57 & 8.59 & 8.65 & 8.68 & 8.63 \\
\hline Crude fiber & 14.81 & 6.53 & 6.55 & 6.55 & 6.68 \\
\hline Nitrogen free extract & 49.74 & 42.78 & 42.53 & 42.59 & 42.35 \\
\hline Ash & 12.89 & 8.55 & 8.58 & 8.68 & 8.71 \\
\hline \multicolumn{6}{|c|}{ Calculated energy values $(\mathrm{kcal} / 100 \mathrm{~g})$} \\
\hline Gross energy $^{2}$ & 367 & 447 & 446 & 446 & 446 \\
\hline Digestible energy $^{3}$ & - & 254 & 301 & 310 & 326 \\
\hline Digestible protein ${ }^{2}$ & - & 27.11 & 27.62 & 28.36 & 29.75 \\
\hline $\mathrm{P} / \mathrm{E}$ ratio $\mathrm{mg} \mathrm{CP} / \mathrm{DE} \mathrm{kcal}$ & - & 87.6 & 87.7 & 87.9 & 88.0 \\
\hline
\end{tabular}


Table 3: Essential oil and predominant effective compounds of the dried basil leaves.

\begin{tabular}{lc}
\hline \multicolumn{1}{c}{ Compound } & Concentration \% \\
\hline Essential oil & 1.51 \\
$\%$ of the oil extraction & \\
Linalool & 10.20 \\
Methyl chavecol & 14.99 \\
Ocimene & 21.64 \\
\hline
\end{tabular}

The effects of using DBL as feeding attractants on the body composition of hybrid tilapia are shown in (Table 6). No significant differences
$(\mathrm{P}>0.05)$ were found in dry matter and ash contents. However, addition of DBL resulted in an increase in protein content and a decrease in lipid and ash contents of fish. Palatability of the experimental diets was increased as DBL level increased in the experimental diets. It ranged from 66.52 to $91.57 \%$. The best palatability index was found for diets containing $2 \% \mathrm{DBL}$. It recorded $91.57 \%$ vs $66.52 \%$ for the control diet (Table 7). Similar results were obtained for voluntary feed consumed. Feed waste percent decreased from $33.48 \%$ for the control diet to $8.43 \%$ for the diet contained $2 \%$ DBL

Table 4: Apparent digestibility coefficient (ADC) of experimental diets containing different levels of dried basil leaves.

\begin{tabular}{|c|c|c|c|c|c|}
\hline \multirow{2}{*}{ Item } & \multicolumn{4}{|c|}{ Diet No } & \multirow{2}{*}{ SEM $^{*}$} \\
\hline & 1 & 2 & 3 & 4 & \\
\hline Dry matter & $65.63^{\mathrm{a}}$ & $67.05^{\mathrm{a}}$ & $69.21^{\mathrm{a}}$ & $71.19^{\mathrm{a}}$ & 1.12 \\
\hline Crude protein & $80.80^{\mathrm{b}}$ & $82.25^{\mathrm{b}}$ & $84.38^{\mathrm{ab}}$ & $88.46^{\mathrm{a}}$ & 1.19 \\
\hline Ether extract & $89.68^{\mathrm{a}}$ & $83.61^{\mathrm{ab}}$ & $80.68^{\mathrm{b}}$ & $78.05^{\mathrm{b}}$ & 1.76 \\
\hline Crude fiber & $22.59^{\mathrm{a}}$ & $23.28^{\mathrm{a}}$ & $23.52^{\mathrm{a}}$ & $24.12^{\mathrm{a}}$ & 0.44 \\
\hline NFE & $58.84^{\mathrm{a}}$ & $55.79^{\mathrm{a}}$ & $51.23^{\mathrm{ab}}$ & $46.94^{b}$ & 1.47 \\
\hline Energy & $75.49^{c}$ & $78.58^{\mathrm{bc}}$ & $81.14^{\mathrm{ab}}$ & $85.22^{\mathrm{a}}$ & 1.98 \\
\hline
\end{tabular}

* Values in the row having a common superscript letter are not significantly different $(\mathrm{P}>0.05)$.

** Standard error of the means derived from the analysis of variance.

Table 5: Growth rate, feed conversion and nutrient efficiencies utilization of hybrid tilapia fingerlings fed diets containing different levels of DBL.

\begin{tabular}{|c|c|c|c|c|c|}
\hline \multirow{2}{*}{ SEM $^{1}$} & \multicolumn{4}{|c|}{ SEM $^{1}$} & \multirow{2}{*}{ SEM } \\
\hline & $1(0.0 \%)$ & $2(0.5 \%)$ & $3(1 \%)$ & $4(2.0 \%)$ & \\
\hline Initial Wt. g/fish & 13.06 & 13.01 & 13.02 & 13.20 & 0.03 \\
\hline Final Wt. g/fish & $29.56^{\mathrm{b}}$ & $31.60^{\mathrm{b}}$ & $36.49^{\mathrm{ab}}$ & $38.96^{\mathrm{a}}$ & 1.54 \\
\hline Gain g/fish & $16.49^{\mathrm{b}}$ & $18.36^{\mathrm{b}}$ & $23.47^{\mathrm{ab}}$ & $25.76^{\mathrm{a}}$ & 1.53 \\
\hline $\mathrm{SGR}^{2} \% /$ day & $0.73^{\mathrm{b}}$ & $0.80^{\mathrm{ab}}$ & $0.92^{\mathrm{ab}}$ & $0.97^{\mathrm{a}}$ & 0.04 \\
\hline Survival rate $\%$ & $95.0^{\mathrm{a}}$ & $100^{\mathrm{a}}$ & $95.0^{\mathrm{a}}$ & $100^{\mathrm{a}}$ & 1.64 \\
\hline Feed intake g/fish & $59.43^{\mathrm{a}}$ & $61.16^{\mathrm{a}}$ & $68.41^{\mathrm{a}}$ & $70.64^{a}$ & 0.03 \\
\hline DM intake $\mathrm{g} /$ fish & $55.16^{\mathrm{a}}$ & $56.05^{\mathrm{a}}$ & $62.66^{\mathrm{a}}$ & $64.57^{\mathrm{a}}$ & 0.03 \\
\hline Condition factor ${ }^{3}$ & $1.74^{\mathrm{a}}$ & $1.69^{\mathrm{a}}$ & $1.79^{\mathrm{a}}$ & $1.85^{\mathrm{a}}$ & 2.07 \\
\hline $\mathrm{FCR}^{4}$ & $3.35^{\mathrm{a}}$ & $3.01^{\mathrm{ab}}$ & $2.67^{\mathrm{b}}$ & $2.51^{\mathrm{b}}$ & 0.13 \\
\hline $\mathrm{PER}^{5}$ & $0.89^{c}$ & $0.99^{\mathrm{bc}}$ & $1.11^{\mathrm{ab}}$ & $1.19^{\mathrm{a}}$ & 0.05 \\
\hline $\mathrm{PPV}^{6} \%$ & $16.07^{\mathrm{a}}$ & $16.76^{\mathrm{a}}$ & $18.34^{\mathrm{a}}$ & $18.43^{\mathrm{a}}$ & 0.78 \\
\hline $\mathrm{ER}^{7} \%$ & $10.63^{\mathrm{a}}$ & $10.20^{\mathrm{a}}$ & $11.20^{\mathrm{a}}$ & $11.04^{\mathrm{a}}$ & 0.47 \\
\hline
\end{tabular}

* Values in the row having a common superscript letter are not significantly $(\mathrm{P}>0.05)$.

1. Standard error of the means derived from the analysis of variance.

2. Specific growth rate $=100$ ( $\operatorname{Ln}$ final weight-Ln Initial weight)/days

3. Condition factor $=100\left[\right.$ final wt./(total length) $\left.{ }^{3}\right]$.

4. Feed conversion ratio $=$ dry matter intake/gain.

5. Protein efficiency ratio = weight gain $/$ protein intake.

6. Productive protein value $=100$ (protein gain/protein intake).

7. Energy retention $=100$ (gross energy gain/gross energy intake). 
level. However, it was declined as DBL levels increased in diets of tilapia. Consequently, the feed cost to produce one $\mathrm{kg}$ of fish (Incidence cost) was significantly $(\mathrm{P}<0.05)$ lower in the diet containing 2\% DBL level. Profit index greatly improved by using of basil leaves as a feeding attractant for fingerlings of hybrid tilapia (Table 8). Diet containing $2 \%$ DBL level was more economic than the control diet and other diets supplemented with DBL levels.

\section{Discussion}

The present study indicated that the appetite of hybrid tilapia is influenced by the concentration of feed attractants. Apparent digestibility coefficients were increased for dry matter, crude protein and energy as increased of DBL levels in diets. On the other hand, digestibilities of lipid and NFE were decreased with increasing of DBL levels. Increasing levels of dried basil

Table 6: Body composition of hybrid tilapia fingerlings* fed diets containing different levels of dried basil leaves.

\begin{tabular}{ccccc}
\hline \multirow{2}{*}{ Diet No (DBL levels) } & \multirow{2}{*}{ Dry matter \% } & \multicolumn{3}{c}{ \% on DM basis } \\
\cline { 3 - 5 } & 19.86 & Crude protein & Ether extract & 16.32 \\
\hline Initial fish & $22.81^{\mathrm{a}}$ & 63.08 & $20.95^{\mathrm{a}}$ & $10.67^{\mathrm{a}}$ \\
$1(0.0 \%)$ & $21.24^{\mathrm{a}}$ & $71.29^{\mathrm{ab}}$ & $18.37^{\mathrm{ab}}$ & $10.34^{\mathrm{a}}$ \\
$2(0.5 \%)$ & $21.15^{\mathrm{a}}$ & $71.84^{\mathrm{ab}}$ & $18.15^{\mathrm{ab}}$ & $10.01^{\mathrm{a}}$ \\
$3(1.0 \%)$ & $20.03^{\mathrm{a}}$ & $72.15^{\mathrm{a}}$ & $18.03^{\mathrm{b}}$ & $9.82^{\mathrm{a}}$ \\
$4(2.0 \%)$ & 0.54 & 0.64 & 0.51 & 0.55 \\
SEM $^{* *}$ & & & &
\end{tabular}

* Values in the row having a common superscript letter are not significantly different $(\mathrm{P}>0.05)$.

** Standard error of the means derived from the analysis of variance.

Table 7: Voluntary feed intake, Playability index and feed waste percent of hybrid tilapia fingerlings* fed diets containing different levels of dried basil leaves.

\begin{tabular}{cccc}
\hline Diet No & VFI $^{1}$ & Palatability index $^{\mathbf{2}}$ & Feed waste $^{\mathbf{3}} \%$ \\
\hline $1(0.0 \%)$ & $8.18^{\mathrm{c}}$ & $66.52^{\mathrm{d}}$ & $33.48^{\mathrm{a}}$ \\
$2(0.5 \%)$ & $9.71^{\mathrm{c}}$ & $74.49^{\mathrm{c}}$ & $25.44^{\mathrm{b}}$ \\
$3(1.0 \%)$ & $12.46^{\mathrm{b}}$ & $82.90^{\mathrm{b}}$ & $17.10^{\mathrm{c}}$ \\
$4(2.0 \%)$ & $14.68^{\mathrm{a}}$ & $91.57^{\mathrm{a}}$ & $8.43^{\mathrm{d}}$ \\
$\mathrm{SEM}^{4}$ & 0.96 & 3.56 & 3.55 \\
\hline
\end{tabular}

\footnotetext{
* Values in the row having a common superscript letter are not significantly different $(\mathrm{P}>0.05)$.

1. Voluntary feed intake $=$ Introduced feed for fish based on 3\% body weight-uneaten feed, according to Kaushik (2000).

2. Palatability index $=100 x(\mathrm{FVI} /$ introduced feed $)$.

3. Feed waste $\%=100 x$ (Uneaten feed/introduced feed for fish).Voluntary feed intake, palatability index and feed wastes were calculated during the last two weeks.

4. Standard error of the means derived from the analysis of variance.
}

leaves in the experimental diets resulted in an improvement in body weight, gain, SGR and FCR. These results suggested that hybrid tilapia uses chemoreaction as well as olfaction to detect and select its feed. This pattern is similar to that observed by several researchers (Takei, 1967; Harada, 1990; Abou Zied, 1998; Sakr, 2003; El-Dakar, et al. 2004 and Shalaby, 2004). Tandler et al. (1982) reported that appetite is a good criterion for testing effectiveness of feed attractants. In this connection, palatability index had a positive relationship with levels of dried basil leaves in hybrid tilapia diet. It recorded $66.52,74.49,82.90$ and $91.57 \%$ for diets supplemented with $0,0.5,1.0$ and $2.0 \%$ DBL, respectively. Mcleese (1970) found that increasing of DL-alanine as a feeding attractant increased the feeding behavior responses in American lobster. Furthermore, Mackie and Shelton (1972) also, reported that there was a direct relationship in the lobster between the concentration of lipid free squid extract and the 
Table 8: Cost-benefit analysis of hybrid tilapia, O. niloticus x $O$. aurous, fed different levels of dried basil leaves.

\begin{tabular}{lcccc}
\hline & \multicolumn{3}{c}{ Diet No. } & \\
\cline { 2 - 5 } Item & $\mathbf{1}$ & $\mathbf{2}$ & $\mathbf{3}$ & $\mathbf{4}$ \\
\hline Cost $^{1}$ per kg diet & 1.21 & 1.24 & 1.28 & 1.34 \\
Incidence cost ${ }^{2}$ & $4.38^{\mathrm{a}}$ & $4.09^{\mathrm{ab}}$ & $3.72^{\mathrm{ab}}$ & $3.65^{\mathrm{b}}$ \\
Relative IC (\%) & 100 & 93.38 & 84.93 & 83.33 \\
Profit index & $1.61^{\mathrm{a}}$ & $1.72^{\text {ba }}$ & $1.89^{\mathrm{a}}$ & $1.92^{\mathrm{a}}$ \\
Relative PI (\%) & 100 & 107 & 117 & 119 \\
\hline
\end{tabular}

1. Costs were as common commercial feeds in local markets during 2005. Prices in Egyptian pounds, 1 Euro equales 7.5 EP.

2. Incidence cost $=$ feed cost consumed $/ \mathrm{kg}$ fish produced.

3. Profit index $=$ value of fish crop/cost of feed consumed.

food searching activity. Our previous results with dried marjoram leaves confirmed the above findings (El-Dakar, et al. 2004) and similar results were obtained by Sakr, (2003).

In the present study, performance of hybrid tilapia was markedly improved by adding DBL in their diets due to its olfaction effect, which plays an important role in the orientation of food in fish (Kleerekoper, 1969 and Hara, 1973). Olfactory feed ingredients were found to enhance growth through their ability to act as feeding enhancers. That is for their ability to induce fish to eat more feed than in normal or for their power to change feeding preferences when added in small amounts to a less preferred diet (Adams, et al. 1988). In addition, basil leaf meal may be acting on growth, feed and protein conversion, and nutrient retention efficiencies by its constitution of the volatile oil. The DBL used in this work was rich in ocimene, methyl chavecol and linalool which were the predominant effective compounds in the volatile oil. Similar results were obtained by Abou Zied (1998); Sakr (2003); El-Dakar (2004); El-Dakar et al. (2004); El-Dakar et al. (2005) and ElDakar et al. (2007). In this connection, Harada (1992) found that spices were highly effective in attraction for fish and shellfish, with special reference to strong effect for basil. Most plants that belong to family labiatae including basil, marjoram and peppermint are good feeding attractants. Inclusion of DBL with increased levels for hybrid tilapia diets gave better growth response and conversion of both feed and protein. This may show the possibility that the
DBL plays an important role in the exploratory and feeding behavior of hybrid tilapia. This may be due to its digestive and stimulant effect (Garland, 1993), as well as nice fragrant and volatile oil (Abo zeid, 1989), controlling and buffering the conditions of the stomach and intestine (Boulos, 1983). Furthermore, medicinal herbs may be optimal additives of artificial diets for aquatic animals from the standpoint of their antimicrobial and antiseptic action (Kanda, et al. 1971).

Supplementation of hybrid tilapia diets with DBL resulted in an increase of protein content and decrease in lipid and ash contents. The above results may explain increasing of voluntary feed intake and palatability index of diets containing graded levels of DBL. Results also showed a higher significant $(\mathrm{P}<0.05)$ palatability index for diets supplemented with $2 \%$ DBL followed by 1.0 then $0.5 \%$ DBL. While the control diet gave the lowest palatability index. In contrast, feed waste percent consequently decreased as DBL levels increased in diets. Feed waste percent was 8.43 vs $33.48 \%$ for the diet supplemented $2 \%$ DBL and the control diet, respectively. Axler et al. (1996) and El-Dakar et al. (2004) found similar results. Reduction of feed waste for diet containing DBL levels resulted in a negative response of incidence cost and a positive effect of profit index. Therefore, the diet containing 2\% DBL level was superior economically followed by that contained $1 \%$ level than other tested diets. The feed cost to produce one kilogram of fish (incidence cost) was 3.65LE when fish fed diet contained 2\% DBL under the present 
condition, it decreased by $27 \%$ from those fed the control diet. Similar results were obtained by Mendoza et al. (1997); Abd Elmonem et al. (2002); Sakr (2003); Shalaby et al. (2003); ElDakar (2004) and El-Dakar et al. (2004).

\section{Conclusion}

Dried basil leaves had a strong attraction effect for fish. Inclusion BML up to $2 \%$ in tilapia feeds gave a positive response to growth, feed and protein conversion, nutrient utilization and apparent digestibility of DM, CP and energy. It may be considered BML as an environment friendly feedstuff due to reduces the feed waste into rearing environment.

\section{References}

Abd Elmonem, A., Shalaby, S.M.M. \& El Dakar, A.Y. 2002. Response of red tilapia to different levels of some medicinal plants by-products black seed and roquette seed meal. Proceeding, of the $1^{\text {st }}$ Scientific Conference on Aquaculture 13-15 December 2002, El Arish, Egypt, pp. 247.

Abou Zeid, E.N. 1989. Aromatic plants and its pharmaceutical and agricultural products. Academic Press, Egypt.

AbouZied, R.M. 1998. Evaluation of some medicinal plants as a feed additive in diets of Nile tilapia (Oreochromis niloticus). M.Sc., Faculty of Agriculture, El-Fayoum, Cairo University.

Adams, M.A., Johnsen, P.B. \& Hong Qi, Z. 1988. Chemical enhancement of feeding for the herbivorous fish Tilapia zillii. Aquaculture, 72 (1-2): 95-107.

Adams, R.P. 1989. Identification of essential oils by Ion trap mass spectroscopy. Academic Press, New York.

AOAC 1990. Official methods of analysis of the association of official analytical chemists. $15^{\text {th }}$ edn, Association of official analytical chemists, Virginia, USA.
Atwa, A.M. 1997. Evaluation of the nutritive value of black seed meal (Nigella sativa) in diests of Nile tilapia(Oreochromis niloticus, Trewavas) M.Sc., Faculty of Agriculture, Alexandria University.

Axler, R., Larsen, C., Tikkanen, C., McDonald, M., Yokom, S. \& Aas, P. 1996. Water quality issues associated with aquaculture: A case study in mine pit lakes. Water Environment Research, 68(6): 995-1101.

Balbaa, S.I., Hila, S.H. \& Zaki, A.Y. 1981. Medicinal plant constituents. $3^{\text {th }}$ edn, General organization for University and school books.

Boulos, L. 1983. Medicinal plants of North Africa. Reference Publications, Inc., Algonac, Michigan, USA.

Duncan, D.B. 1955. Multiple range and multiple $F$ tests. Biometrics, 11, 1-42.

EI Dakar, A.Y. 2004. Growth response of hybrid tilapia, Oreochromis niloticus $x$ Oreochromis auraus, to diets supplemented to different levels of caraway seeds. Mansoura University Journal of Agricultural Sciences, 29 (11): 6083-6094.

El Dakar, A.Y., Hassanien, G.D.I., Seham, S., Gad \& Sakr, S.E. 2004. Use of Medical and Aromatic Plants in Fish Diets: I. Effect of dried marjoram leaves on performance of hybrid tilapia Oreochromis niloticus x Oreochromis aureus, fingerlings. Journal of the Egyptian Academic Society for Environment Development, (B.Aquaculture), 5 (1): 67-83.

EI Dakar, A.Y., Shalaby, S.M. \& Saoud, I.P. 2007. Assessing the use of a dietary probiotic/prebiotic as an enhancer of spinefoot rabbitfish Siganus rivulatus survival and growth. Aquaculture Nutrition, 13 (6): 407-412.

EI Dakar, A.Y., Shymaa, M.M., Shalaby, S.M., Abead \& M .M. , Khalafala 2005. Use of spices as feeding stimulants in diets of marine shrimp, Penaeus japonicus. Egyptian Journal of Nutrition and Feeds, 8 (1): 1065-1076.

Garland, S. 1993. The complete book of herbs \& spices, Readers Digest, New York. 
Hanafy, M.M. 1995. The use of anise (Pimpinella anisum), fennel (Foeniculum Vulgare) and ginger (Zingiber officinale roscoe) as a feed additive in the nutrition of broilers. M.Sc., Faculty of Agriculture, Alexandria University.

Hara, T.J. 1973. Olfactory responses to amino-acids in rainbow trout salmo-gairdneri. Comparative Biochemistry and Physiology A, 44 (2): 407-416.

Harada, K. 1987. Favorite and disliked constituents for aquatic animals. Kansui, 276: 25-33.

Harada, K. 1990. Attraction activities of spices for oriental weatherfish [Misgurnus anguillicaudatus] and yellowtail [Seriola quinqueradiata]. Bulletin of the Japanese Society of Scientific Fisheries (Japan), 56 (12): 2029-2033.

Harada, K. 1992. Feeding attraction activity of fragrant and pungent spice extractes in black abalone, Haliotis discus. In Abalone of the world: Biology, fisheries and culture, eds. S.A. Shepherd, M.J. Tenger \& S.A.G. Proo, Fishing News Books, Oxford, UK: 193-200.

Harada, K. \& Kawasaki, O. 1982. The attractive effect of seaweeds based on the behavioral responses of young herbivorous abalone Haliotis discus. Bulletin of the Japanese Society of Scientific Fisheries (Japan), 48 (5): 617-621.

Kanda, T., Yamamoto, T. \& Saito, H. 1971. Antimicrobial and antiseptic properties of spices. Food Industrial, 14: 736-776.

Karali, M.A. 1995. The use of coriander (Coriandrum sativum), peppermint (Mentha piperita) and celery (Apium graveolens) as a feed additives in pekin duck ration. M.Sc., Faculty of Agriculture, Alexandria University.

Kaushik, S.J. 2000. Feed allowance and feeding practices. Cahiers-Options-Mediterraneennes, 47: 53-59.

Kleerekoper, H. 1969. Olfaction in fishes, Indiana University Press, USA.

Lovell, T. 1989. Nutrition and feeding of fish, Van Nostrand Reinhold., New York, USA.
Mackie, A.M. \& Shelton, R.G.J. 1972. A whole animal bioassay for the determination of the food attractants of the Lobster homarus-gammarus. Marine Biology (Berlin), 14 (3): 217-221.

Mcleese, R.G. 1970. Effect of DL-alanine as a feeding attractants for American lobster. Aquaculture Fish. Management, 5 (2): 245-252.

Mendoza, R., Montemayor, J. \& Verde, J. 1997. Biogenic amines and pheromones as feed attractants for the freshwater prawn Macrobrachium rosenbergii. Aquaculture Nutrition (United Kingdom), 3 (3): 167-173.

MStat-C 1988. MStat Director, Crop and Soil Science Department. Michigan State University, East Lansing, MI, USA.

New, M.B. 1985. Feed and feeding of fish and shrimp. A manual on the preparation and presentation of compound feeds for shrimp and fish in Aquaculture, United Nations Development Programme, FAO, Rome.

NRC 1993. Nutrient requirements of fish, National Academy Press, Washington, DC; USA.

Sakr, S.E. 2003. Studies on the feeding attractants for fish. M.Sc., Faculty of Environmental Science, Suez-Canal University.

Shalaby, S.M. 2004. Response of Nile tilapia, Oreochromis niloticus, fingerlings to diets supplemented with differennt levels of fenugreek seeds (Hulba). Mansoura University Journal of Agricultureal Sciences, 29 (5): 2231-2242.

\section{Shalaby, S.M.M., Abd Elmonem, A.I. \& El Dakar, A.Y.} 2003. Enhancement of growth performance, feed and nutrient utilization, of Nile tilapia, Oreochromis niloticus, using of licorice roots (Erksous) as a feed attractive. Journal of the Egyptian Academic Society for.Environment Development (B.Aquaculture), 4 (2): 119-142.

Snedecor, G.W. \& Cochran, W.G. 1974. Statistical methods, $6^{\text {th }}$ edn, Iawa State University Press, Iawa,USA. 


\section{Basil leaves as a feeding attractant}

Takei, M. 1967. Studies on fishes' favorite foods: I. Feeding tests of carp, yellowtail and rainbow trout. Bulletin of the Tokai Regional Fisheries Research Laboratory, 49: 119-129.
Tandler, A., Berg, B.A., Kissil, G.W. \& Mackie, A.M. 1982. Effect of food attractants on appetite and arowth rate of gilthead bream sparus-aurata. Journal of Fish Biology, 20 (6): 673-682. 